Iranian Quarterly Journal of Breast Disease. 2020; 12(4):21.

\section{Original Article \\ Study of Long Noncoding RNA FER1L4 and RB1, as Its Competing Endogenous RNA Network Target Gene, in Breast Cancer}

\author{
Shaghaghi Torkdari $Z^{1}$, Khalaj-Kondori $\mathbf{M}^{{ }^{*}}$, Hosseinpour Feizi MA ${ }^{1}$ \\ ${ }^{1}$ Department of Genetics, Animal Biology Group, Faculty of Natural Sciences, University of \\ Tabriz, Tabriz, Iran
}

Receive: $11 / 9 / 2019$

Accepted: $1 / 1 / 2020$

*Corresponding Author:

khalaj@tabrizu.ac.ir

Ethics Approval: IR.TABRIZU.REC.1398.016

\begin{abstract}
Introduction: Breast cancer is the second most common cause of cancer-related death among females, which requires an exploration for markers to propose a more specific categorization of this cancer. Long noncoding RNAs (lncRNAs), the main subset of noncoding transcripts, are involved in tumorigenic processes. In this study, we investigated the expression of the fer-1-like family member 4 (FERILA) lncRNA and its competitive endogenous RNA network target gene, RB transcriptional corepressor $1(R B 1)$, in ductal carcinoma (invasive and in situ) tissue and its adjacent noncancerous tissue (ANCT). Furthermore, associations of FERIL4 and RBI with various clinical features of the patients were analyzed.
\end{abstract}

Methods: Quantitative real-time PCR was used to measure the expression of the mentioned genes in 61 samples of ductal carcinoma and their ANCTs, and the data were analyzed using ANOVA and $t$ tests.

Results: FERIL expression was not significantly different in breast tumor samples compared with their ANCT samples, while $R B 1$ showed significant downregulation in tumor tissues $(\mathrm{P}=0.008)$. In addition, increased expression of FERIL4 and decreased $R B 1$ expression were significantly correlated with lymph node metastasis in breast cancer patients $(\mathrm{P}<0.05)$.

Conclusion: FERILA is not upregulated in breast cancer tissue. However, $R B 1$ expression is significantly downregulated.

Keywords: IncRNA FER1LA, Breast Cancer, RB1, ceRNA Network 


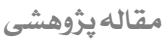

\section{مطالعه RNA طويل غير كد كننده FER1L4 و RB1 به عنوان \\ خن هدف در شبكه ceRNA در سرطان يستان}

زينب شقاقى تركدارى'، محمد خلج كندرى ".، محمدعلى حسينبور فيضى'

' بخش رُنتيك، كروه علوم جانورى، دانشكده علوم طبيعى، دانشًاه تبريز، تبريز، ايران
فصلنامه بيمارى هاى يستان ايران

$|r q \Lambda \leqslant| r(\varepsilon): r \mid-r \cdot$

\section{our?}

مقدمه: سرطان پستان دومين عامل مرگ و مير ناشى از سرطان در بين زنان است كه نيازمند

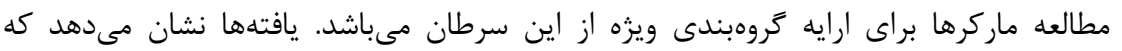

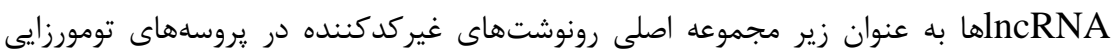

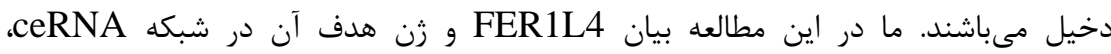

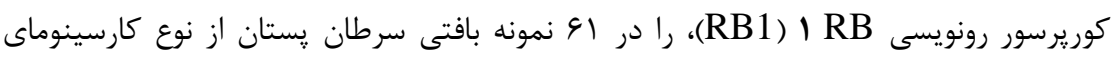

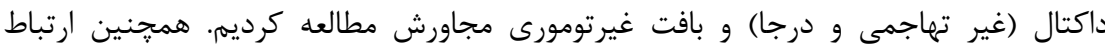

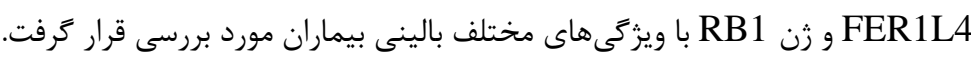
روش بررسى: بيان زنهاى مذكور با استفاده از روش Real time PCR در الونمونه مربوط

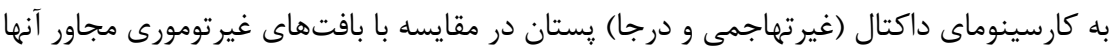

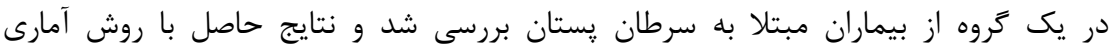
ANOVA

يافتهها: نتايج نشان داد كه FER1L4 تفاوت معنى دارى بين نمونههاى تومورى در مقايسه با

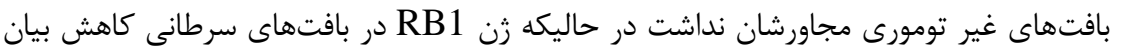

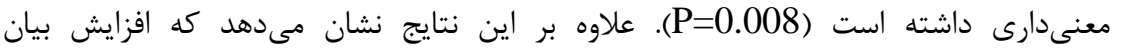
FER1L4 بيماران ارتباط دارد (P<0.05).

نتيجهَيرى: برخلاف مطالعات ييشين، در مطالعه ما افزايش معنىدارى از FER1L4 در سرطان يستان يافت نشد ولى با اين حال بيان زن RB1 به صورت معنى معنى دارى كاهش يافته است. أوازههاى كليدى: FER1L4 lncRNA، سرطان يستان، RB1، شبكه ceRNA

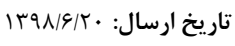

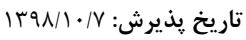

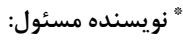
khalaj@tabrizu.ac.ir 


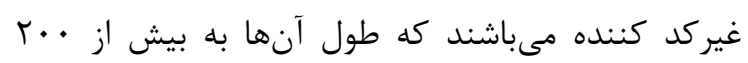
مقدمه

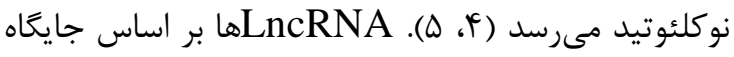

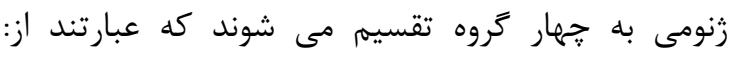
lncRNA lncRNA أنا نقش بسيار مهمى در تنظيم شبكدهاى

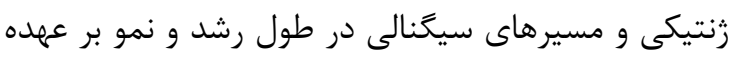

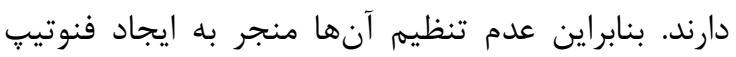

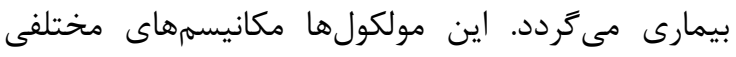

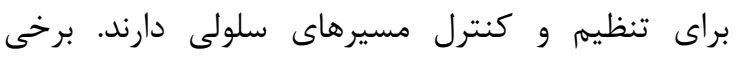

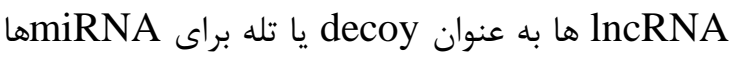

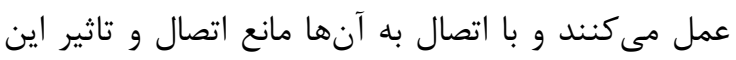

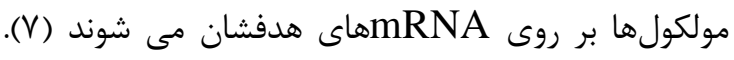
برخى ديكر با تشكيل مارِيجج هاى سه رشتهاى مان مانع اتصال

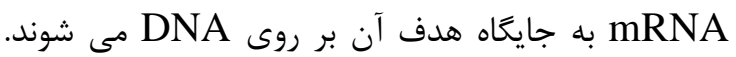

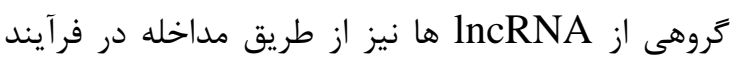

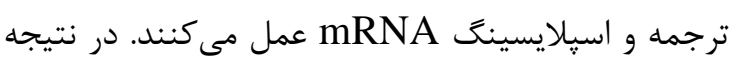
فعاليت مسيرهاى حياتى در يروسه سرطانزايى با تنظيم

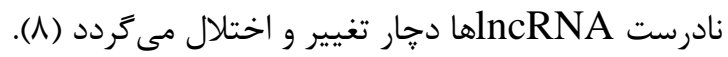

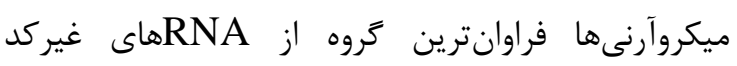

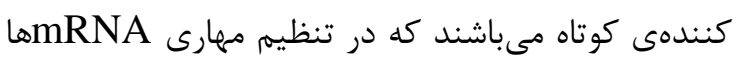

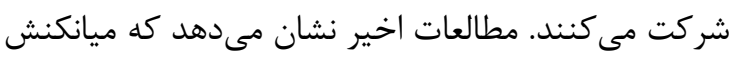

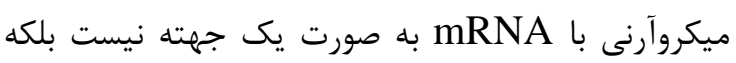

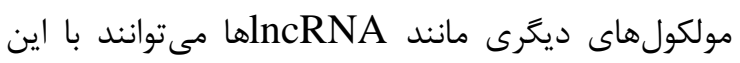

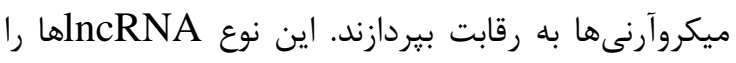

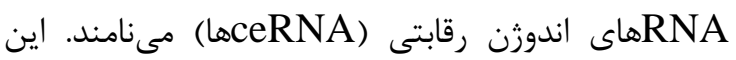
ceRNA

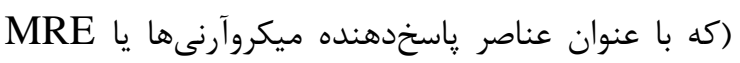

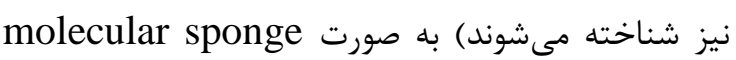

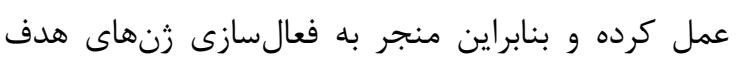

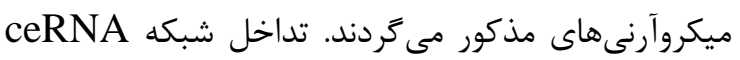

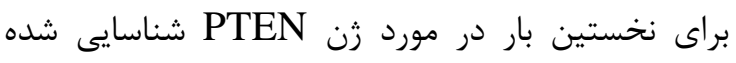
است كه تغيير در اين شبكه در سرطانهاى درن انسانى درنى

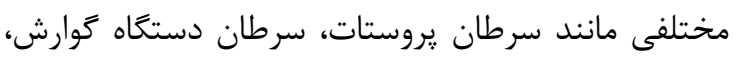

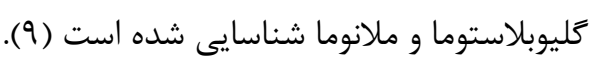
lncRNA

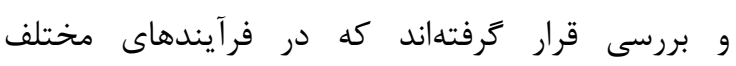

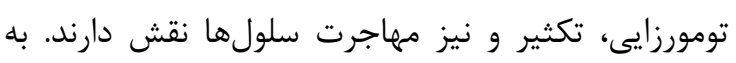
عنوان مثال HOXA-AS2, و و ت

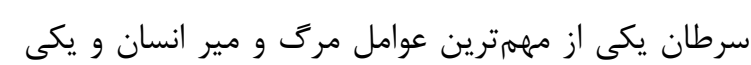
از ير هزينهترين بيمارىهاى جوامع انسانى است كه عه علاوه

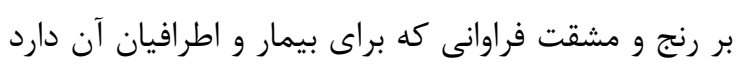

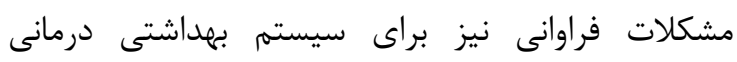

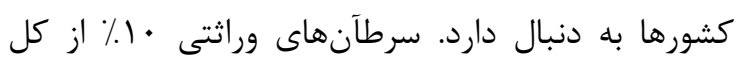

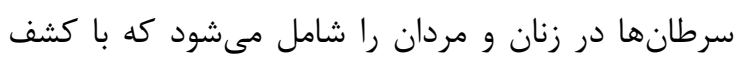
زنهاى جديد دخيل در به ارث رساندن سرطان دها، اين ران

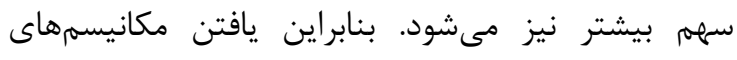

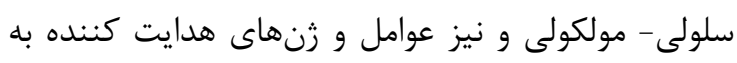
سمت ايجاد سلول سرطانى مىتواند در يافتن راههاى

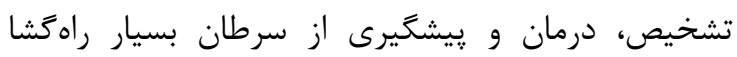
باشد. سرطان رِّتان به عنوان يكى از شايعترين سرطانها در

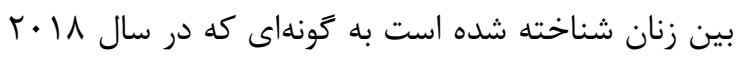

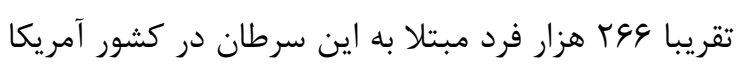

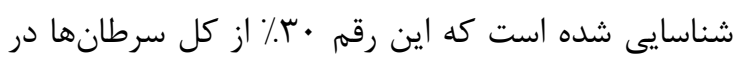

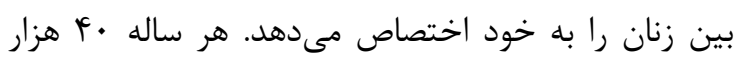

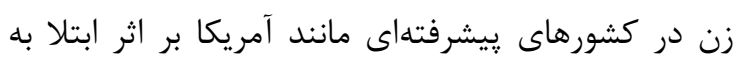

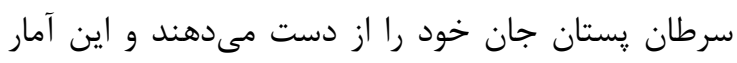

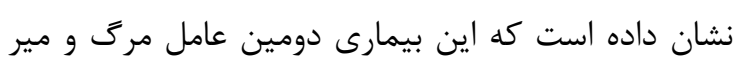

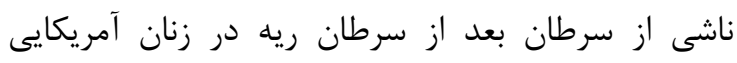

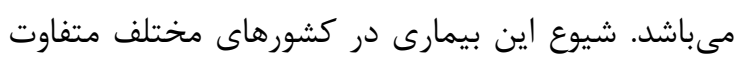

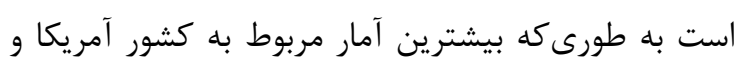

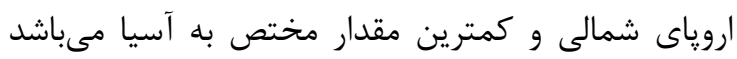

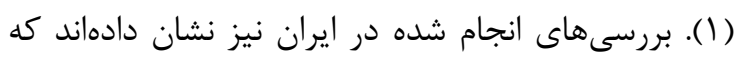

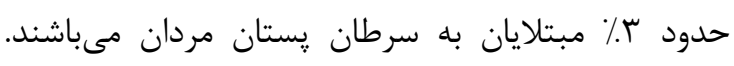

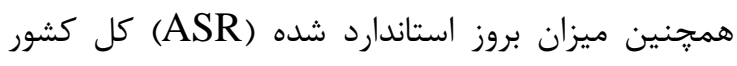

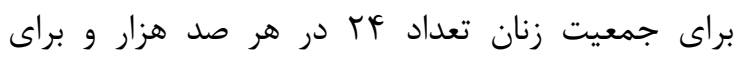

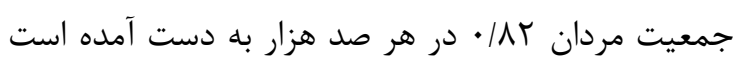

يكى از عوامل موثر در ايجاد سرطان كه امروزه به طور

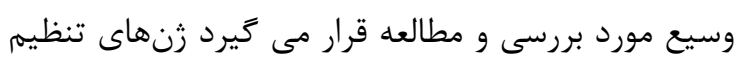

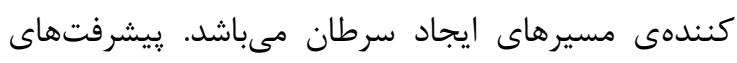

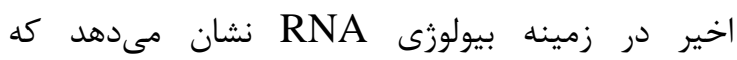
هاى غير كد كننده، مولكول هاى ضرورى هستندكه

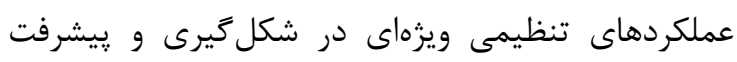
بيمارىها به ويزه سرطان دارند (ا، با، عال).

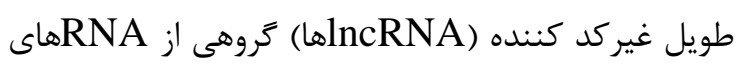


كارسينوماى داكتال درجا نشان دادهاند كه اختلال در تنظيم مسيرهاى اين رن با بيشرفت بيمارى دمان همراه

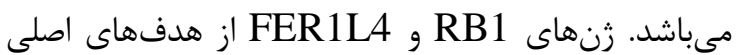
miR-106a-5p در شبكه ceRNA ياد شده مىباشند. از طرف ديگر بيان زنهاى فوق با يكديگر نيز همراهى

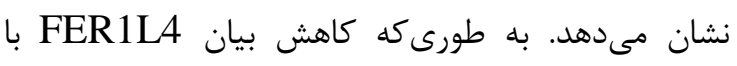

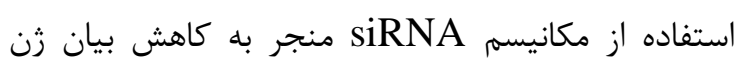

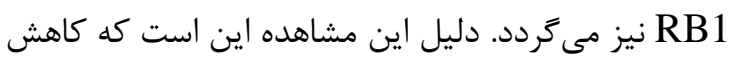

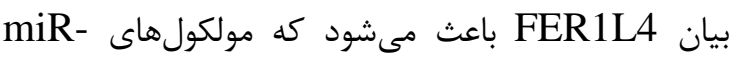
106a-5p

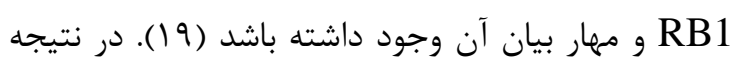

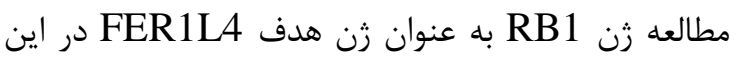

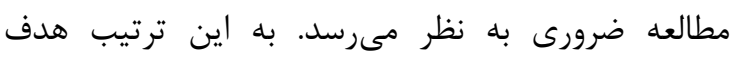

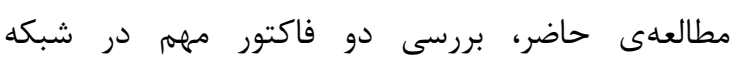
ceRNA

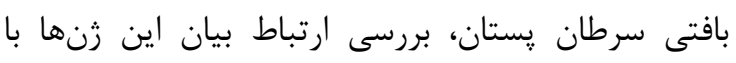

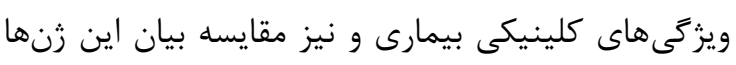

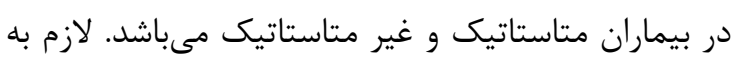
ذكر است كه محققين تا كنون به هيج مطالعهاى در بئن

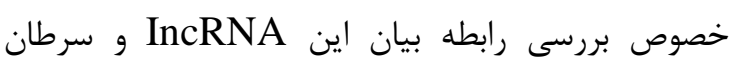

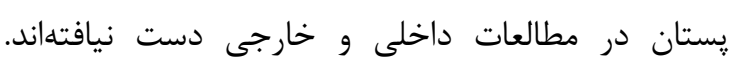

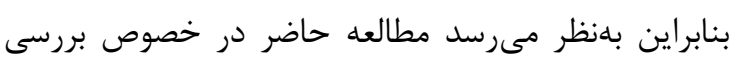
اين رابطه منحصر بفرد مىباشد.

\section{مواد و روشها}

نمونههايى كه در اين مطالعه مورد استفاده قرار كرفته

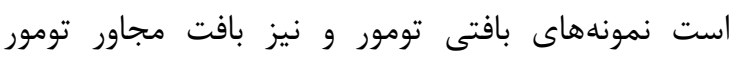

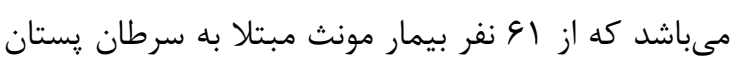

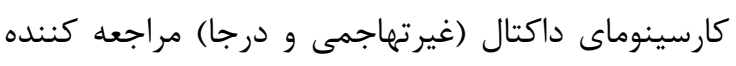

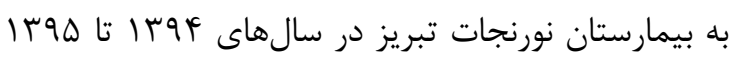

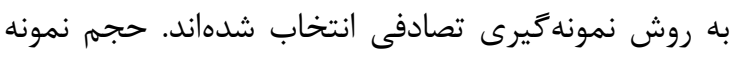

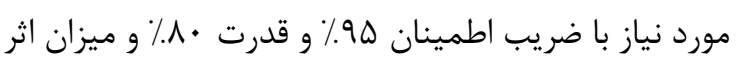

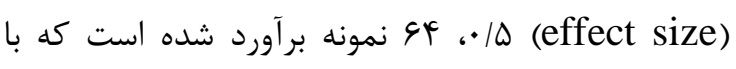

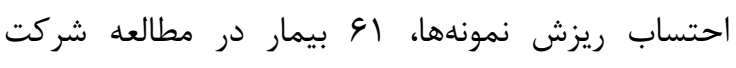

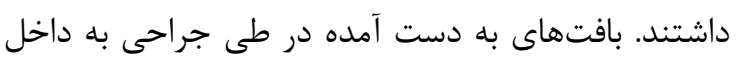

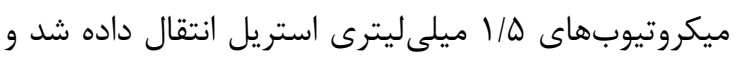

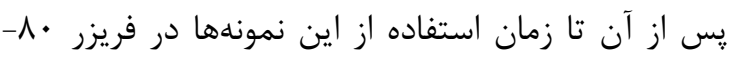

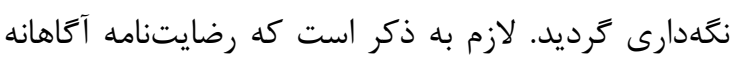

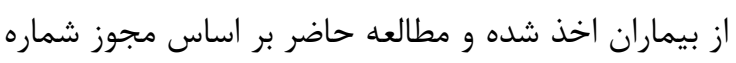

بافتهاى تومورى در مقايسه با بافتهاى سالم حاشيهاى دجار افزايش بيان شده و در نتيجه منجر به افزايش دون تكثير،

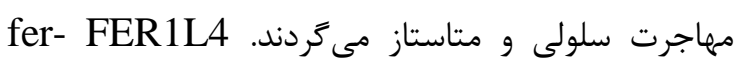
IncRNA يكاى إنى از (1like family member 4) شناخته شده در سال هاى اخير مىباشدكه توسط سانگ و

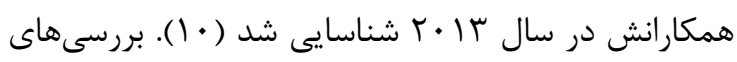

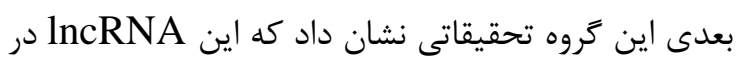

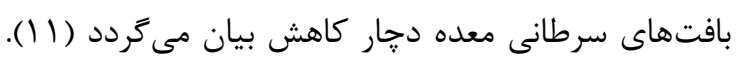

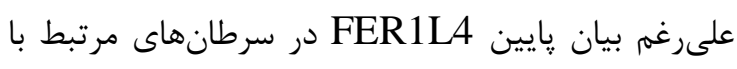

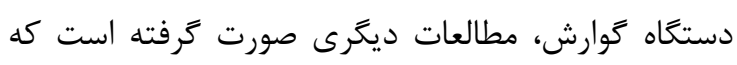
بيان بالاى اين زن در نمونههاى تومورى را نشان دادئن مادهاند

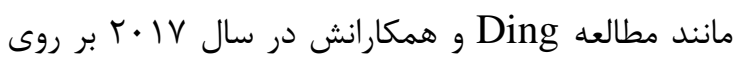

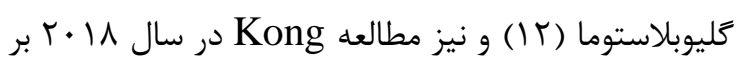

روى كارسينوماى اندومتريال (rاب).

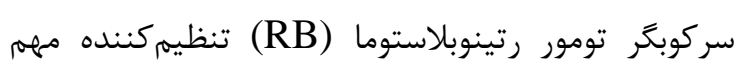

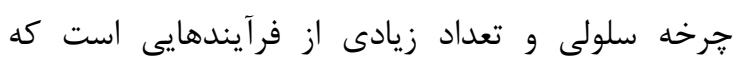

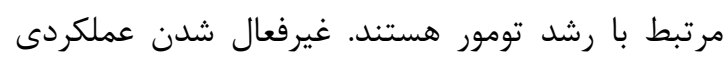

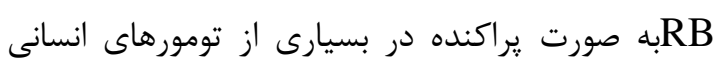

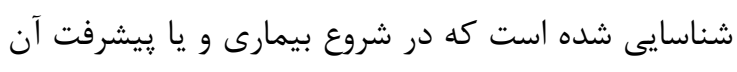
دخيل مىباشد. مطالعات متعددى در حال حاضر نش نشان

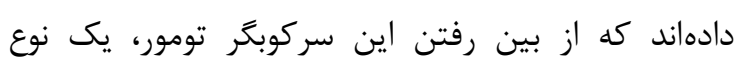

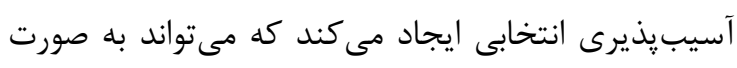

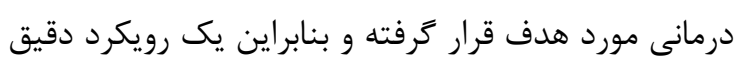

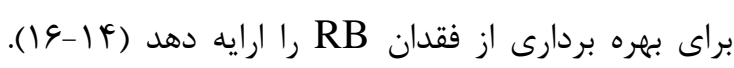

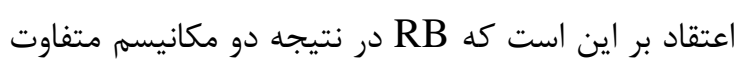

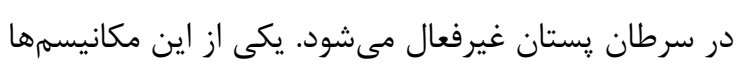

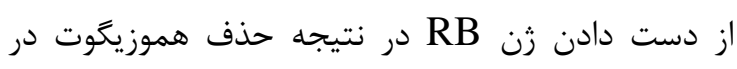
سرطان يستان از نوع triple negative بوده و ور مسير

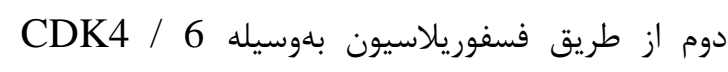

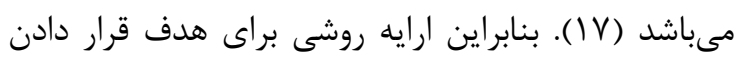

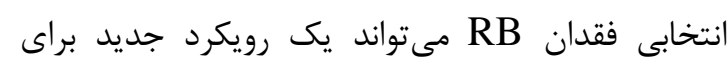

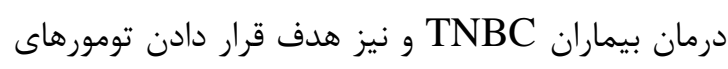

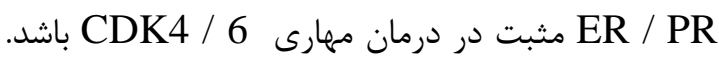

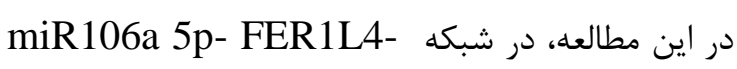

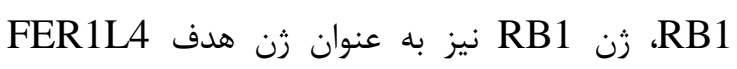

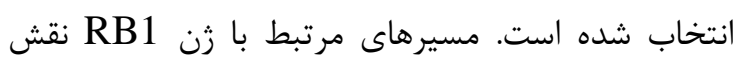

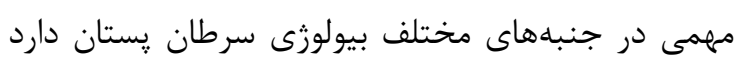

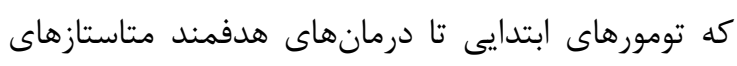

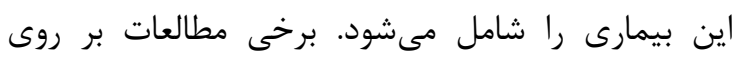


در نمونه هاى مربوط به بافت تومور و نيز نمونههاى مجاور

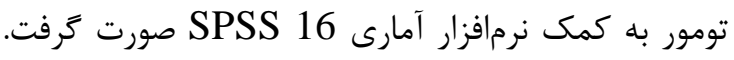

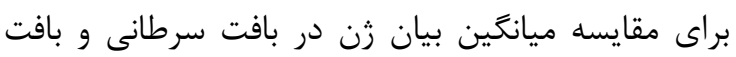

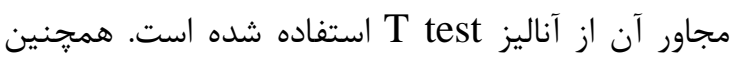
براى مقايسه ميزان بيان زن در بيماران واجد و فاقد إندان

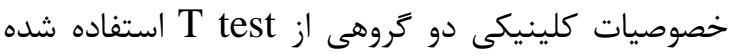

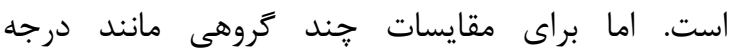

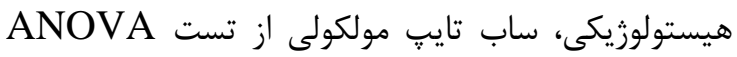
استفاده شده است. در دادهاي مذكور Pvalue كمتر از هـ • • به صورت معنى دار تعريف مى كردد.

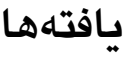
همانطور كه در نمودار 1 مشخص شده است، آناليز دادههاى حاصل از ريل تايم به روش

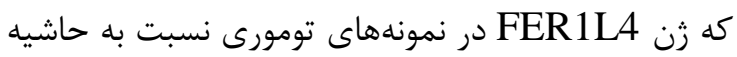

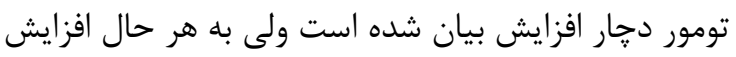

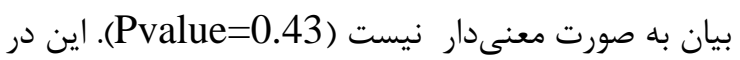

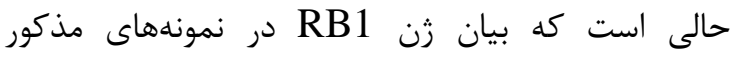
تغييرات معنى دارى نشان داده است (Pvalue=0.008).

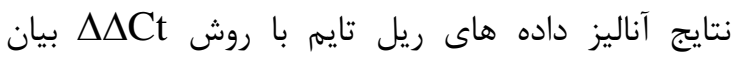

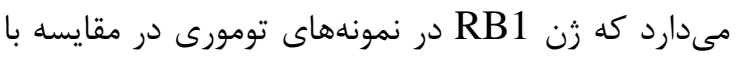

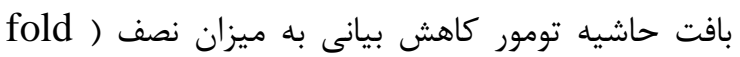

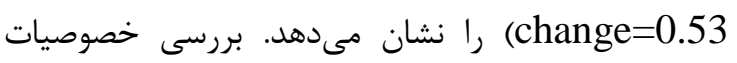

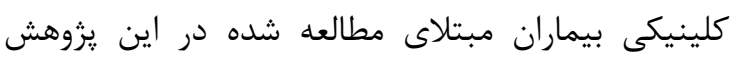

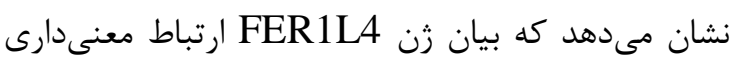

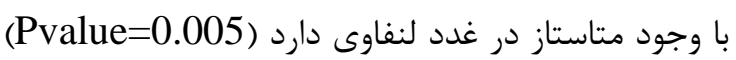

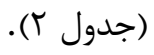

IR.TABRIZU.REC.1398.016 به تاييد كميته اخلاق دانشكاه تبريز رسيده است.

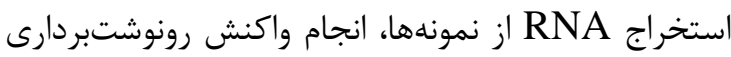

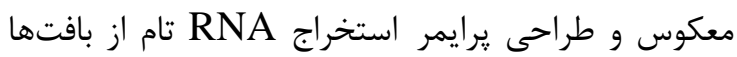
به كمك كيت Rnxplus با يروتوكل كيت مذكور انجام

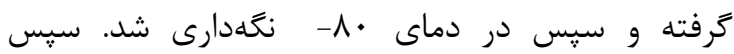

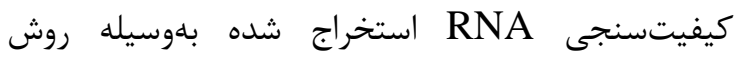
اسيكتروفوتومتر مورد بررسى قرار كرفت. يس از اين مرحله نيز واكنش رونوشت بردارى معكوس جهت سنتز cDNA با استفاده از كيت تاكارا انجام شد. قر جس از اين مرحله با كمك نرمافزار طراحى يرايمرها انجام شد و و ارزيابى اختصاصيت

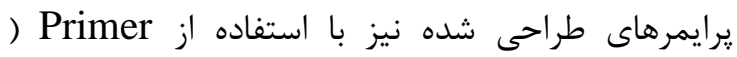
Blast

\section{Real time PCR بررسى بيان زنها با روش} يس از انجام واكنش رونوشت بردارى معكوس، به منظور

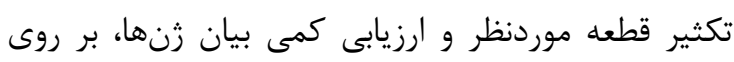
سنتز شده، واكنش Real time PCRA Syber green زنهاى هدف با زن كنترل داخلى GAPDH انسانى

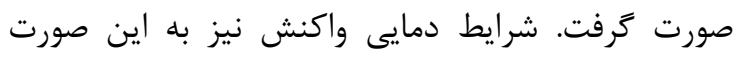

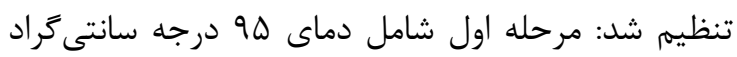

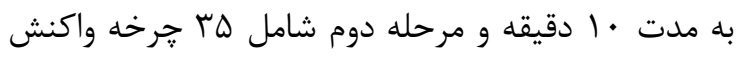

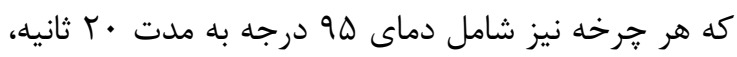

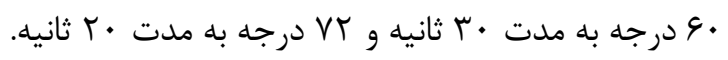
آناليز اطلاعات حاصل از Real time PCR مربوط به به تانه بيان زنهاى هدف و زن كنترل داخلى GAPDH آنساصل انسانى

جدول ا: مشخصات يرايمرهاى استفاده شده در تحقيق

\begin{tabular}{|c|c|c|c|}
\hline طول يرايمر & 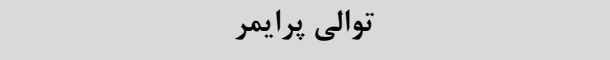 & 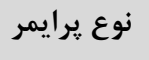 & 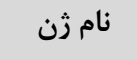 \\
\hline 19 mer & 5-AACGACCCCTTCATTGACC-3 & Forward & \multirow{2}{*}{ GAPDH } \\
\hline 20 mer & 5-TCCACGACATACTCAGCACC-3 & Reverse & \\
\hline 21 mer & 5- ACTGAGAAATGAAGAAGCCAG -3 & Forward & \multirow{2}{*}{ FER1L4 } \\
\hline 21 mer & 5- AAATGTGCAGGTATCCTCATC -3 & Reverse & \\
\hline 21 mer & 5- GCGTGCGCTCTTGAGGTT -3 & Forward & \multirow{2}{*}{ RB1 } \\
\hline 21 mer & 5- AGCCATGCAAGGGATTCCA -3 & Reverse & \\
\hline
\end{tabular}




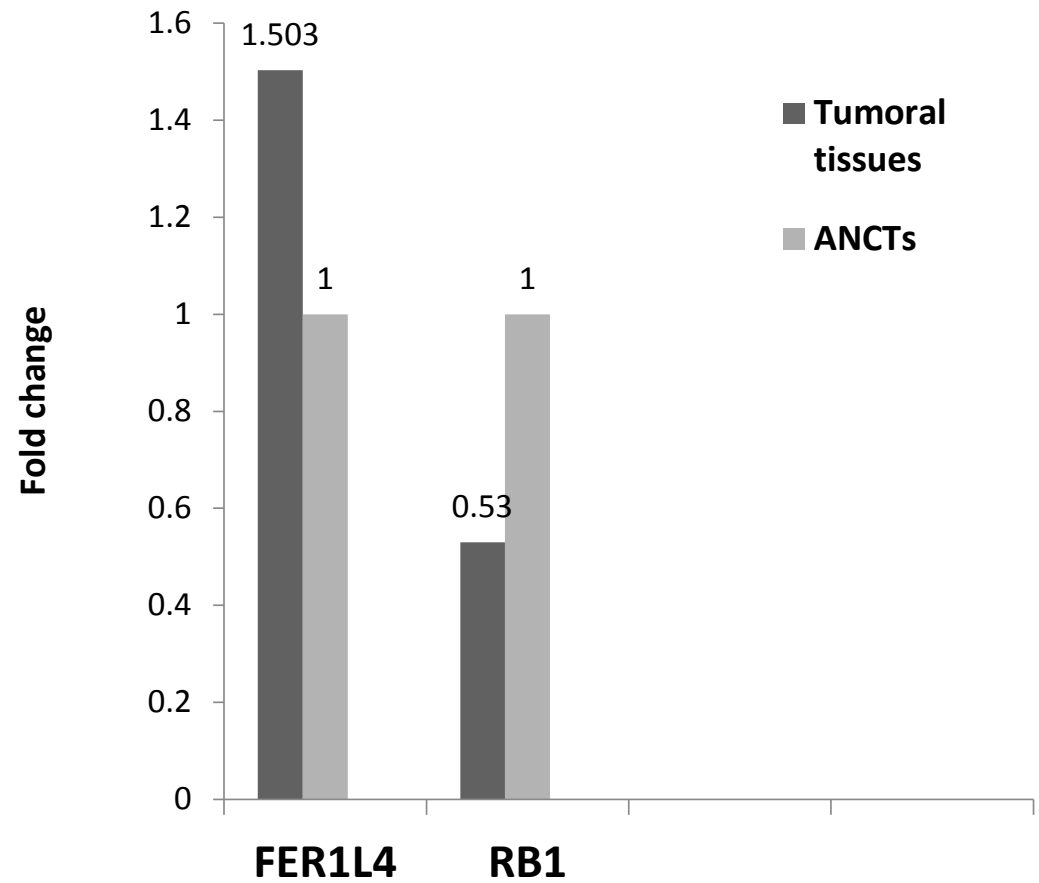

نمودار ا: مقايسه بيان RER1L4 و RB1 در نمونههاى بافت تومورى نسبت به نمونههاى بافت حاشيه تومور

جدول ז: ارتباط بيان ثن FER1L4 در نمونههاى تومورى با خصوصيات كلينيكى بيمارى سرطان بستان

\begin{tabular}{|c|c|c|c|c|}
\hline Pvalue & FER1L4 ميانغين بيان & تعداد & كروهها & خصوصيات \\
\hline \multirow{2}{*}{.1 .99} & $\cdot 119$ & $4 q$ & $4 \cdot>$ & \multirow[b]{2}{*}{ 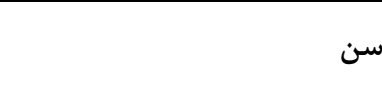 } \\
\hline & $\cdot / \cdot \Delta$ & v & $9 \cdot<$ & \\
\hline \multirow{2}{*}{.1 .94} & .119 & r. & 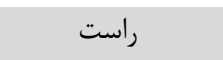 & \multirow{2}{*}{ سمت مبتلا شده } \\
\hline & .111 & re & קֶ: & \\
\hline \multirow{2}{*}{$\cdot / 4 \Delta$} & $\cdot 110$ & is & $<\Delta$ & \multirow{2}{*}{ اندازه تومور (سانتىمتر) } \\
\hline & $\cdot / 1 \mathrm{~F}$ & $\Lambda$ & $>\Delta$ & \\
\hline \multirow{3}{*}{$\cdot / V \Delta$} &.$/ 14$ & 11 & به خوبى تمايزيافته & \multirow{3}{*}{ درجه هيستولوزيكى } \\
\hline & $\cdot / 1 \mathrm{~V}$ & rی & تمايزيافته متوسط & \\
\hline & $\cdot / 1$ & V & تمايزيافته ضعيف & \\
\hline \multirow{2}{*}{1} & $\cdot 1 / \Delta$ & $\Delta \varphi$ & داكتال & \multirow{2}{*}{ مدل هيستولوزيكى } \\
\hline & $\cdot$ & $\cdot$ & لوبولار & \\
\hline \multirow{3}{*}{$\cdot / \pi q$} & $\cdot / 1$ & $r \cdot$ & A لومينال & \multirow{3}{*}{ ساب تايب مولكولى } \\
\hline &.$/ 14$ & $\Delta$ & لومينال B & \\
\hline & $\cdot / \pi$ & r & HER2 & \\
\hline \multirow{4}{*}{$\cdot \mid \Delta \psi \lambda$} & (11 - (1) & TI & 1 & \multirow{4}{*}{ مرحله شناسايى و استيج بيمارى } \\
\hline & .114 & 1 . & r & \\
\hline & .11 & 9 & r & \\
\hline & 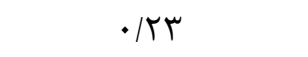 & 10 & r & \\
\hline \multirow{2}{*}{$\cdot / T V \Delta$} &.$/ 14$ & r & 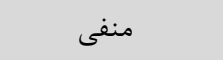 & \multirow{2}{*}{ دركيرى غدد لنفاوى } \\
\hline & $.11 \mathrm{~V}$ & 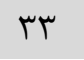 & مثبت & \\
\hline \multirow{2}{*}{$* \cdot \cdot \cdot \Delta$} & $\cdot, 14$ & (i) & 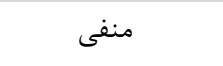 & \multirow{2}{*}{ وجود متاستاز در غدد لنفاوى } \\
\hline & ( & 10 & 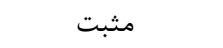 & \\
\hline
\end{tabular}


بررسى ارتباط بيان زن RB1 با خصوصيات كلينيكى

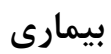
آناليزها و محاسبات نشان مىدهد كه بيان زن RB1 نيز

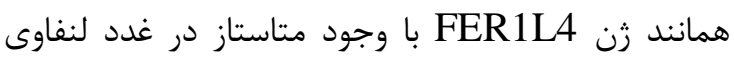

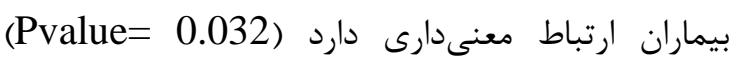
(جدول ץ). ميانگين بيان اين زن در بين كروه بيماران

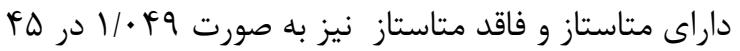

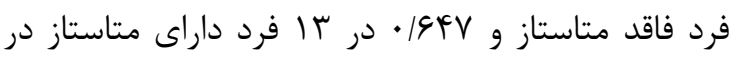

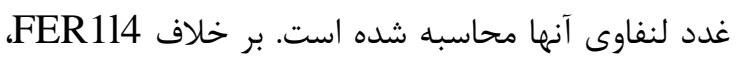

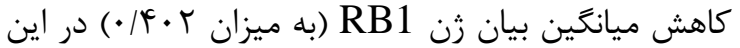
مقايسات در ارتباط با وجود متاستاز در غدد لنفاوى ديده

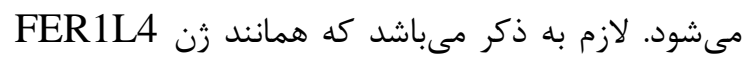
بيان اين زن نيز در ساير خصوصيات كلينيكى بررسى شده كه شامل سن، سمت مبتلا شده، اندازه تومور، درجه دئ باتي

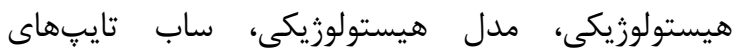
مولكولى، مرحله بيمارى و نيز دركيرى يا عدم دركيرى

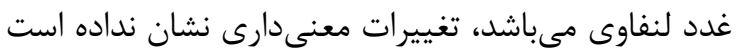

(p value >0.05)
به عبارت ديخر ميانگين بيان اين زن در بين دو گروه مقايسه شده (بيماران داراى متاستاز و فاقد متاستاز) به ديه

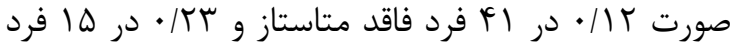
داراى متاستاز در غدد لنفاوى آنها محاسبه شده است. نتايج اين آناليزها نشان مىدهد كه ميانگين بيان رنان

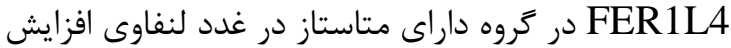

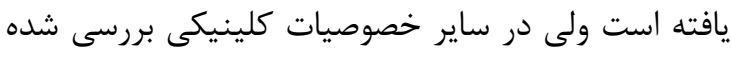
كه شامل سن (كروههاى كمتر و بيشتر از •و سال)، سمت مبتلا شده (راست و جֶٍ)، اندازه تومور (كروههاى كمتر و و بيشتر از ه هانتىمتر)، درجه هيستولوزيكى (شامل كروههاى به خوبى تمايز يافته، تمايز يافته متوسط و تمايز يافته ضعيف)، مدل هيستولوزيكى (داكتال و توبولار)، ساب تايِهاى مولكولى (شامل كروههاى لومينال A، لومينال

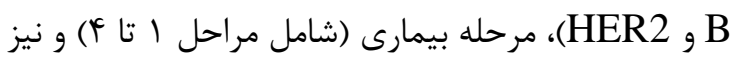
دركيرى يا عدم دركيرى غدد لنفاوى مىباشد، تغييرات معنى دارى مشاهده نشده است (p value>0.05).

جدول ب: ارتباط بيان زن RB1 در نمونههاى تومورى با خصوصيات كلينيكى بيمارى سرطان يستان

\begin{tabular}{|c|c|c|c|c|}
\hline Pvalue & ميانگين بيان RB1 & تعداد & كروهها & خصوصيات \\
\hline \multirow{2}{*}{ - } & $1 / \cdots V$ & $\Delta \cdot$ & $4 \cdot>$ & \multirow[b]{2}{*}{ سن } \\
\hline & $\cdot 19 \Delta \Lambda$ & $\wedge$ & $9 \cdot<$ & \\
\hline \multirow[t]{2}{*}{. } & $\cdot \operatorname{ANY}$ & 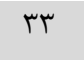 & است & \multirow{2}{*}{ سمت مبتلا شده } \\
\hline & $1 / \cdot V F$ & ra & "ج & \\
\hline \multirow{2}{*}{. KTL } & $1 / F r$ & $\Delta \cdot$ & $<\Delta$ & \multirow{2}{*}{ اندازه تومور (سانتىمتر ) } \\
\hline &.$/ A r v$ & $\wedge$ & $>\Delta$ & \\
\hline \multirow{3}{*}{.$/ 9 F V$} & $.19 V T$ & ir & به خوبى تمايزيافته & \multirow{3}{*}{ درجه هيستولوزيكى } \\
\hline &.$/ 94 \Delta$ & rq & تمايزيافته متوسط & \\
\hline & $1 / \cdot \sqrt{ } 1$ & v & تمايزيافته ضعيف & \\
\hline \multirow{2}{*}{1} & .1909 & $\Delta \wedge$ & داكتال & \multirow{2}{*}{ مدل هيستولوزيكى } \\
\hline & $\cdot$ & $\cdot$ & لوبولار & \\
\hline \multirow{3}{*}{.199} & $\cdot 191$ & $r \cdot$ & A لومينال & \multirow{3}{*}{ ساب تايٍ مولكولى } \\
\hline & $\cdot / k \cdot \Lambda$ & $\Delta$ & B لومينال & \\
\hline & $1 / 1 F$ & $r$ & HER2 & \\
\hline \multirow{4}{*}{. / } & $\cdot 11 \cdot 9$ & ra & 1 & \multirow{4}{*}{ مرحله شناسايى و استيج بيمارى } \\
\hline & I/VTA & 1. & r & \\
\hline & $1 / \cdot v 1$ & 9 & r & \\
\hline & $.194 V$ & r & f & \\
\hline \multirow{2}{*}{$\cdot|f| F \mid$} & $\cdot / \vee 99$ & TF & منفى & \multirow{2}{*}{ دركيرى غدد لنفاوى } \\
\hline & $1 / \cdot V r$ & mF & مثبت & \\
\hline \multirow{2}{*}{. $.1 \cdot r t r$} & $1 / \cdot 4 q$ & is & منفى & \multirow{2}{*}{ وجود متاستاز در غدد لنفاوى } \\
\hline &. $\mid 94 \mathrm{~F}$ & ir & مثبت & \\
\hline
\end{tabular}


عامل انكوزن و نيز بيوماركرى براى شناسايى و يیش آتهمى

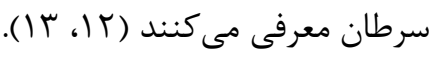

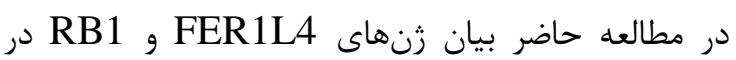
نمونههاى تومورى و حاشيه تومور مورد بررسى و و آناليز قرار كرفت. بيان FER1L4 در نمونههاى تومورى نسيت به نمونههاى حاشيه تومور تغيير معنى برارى نشان نشان نداده

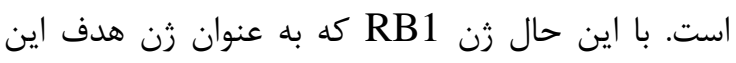
مولكول در شبكه ceRNA مورد بررسى قرار كرفته بود

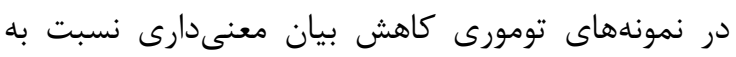
بافت حاشيه تومور داشته است.

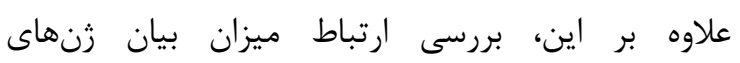

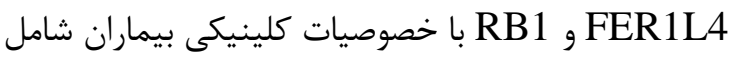

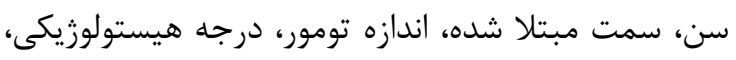

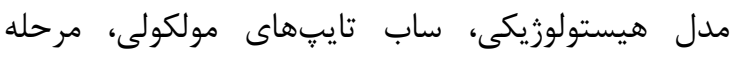

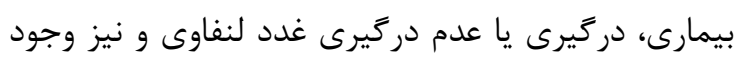
يا عدم وجود متاستاز در غدد لنفاوى نشان داد داد كه مئ ميزان

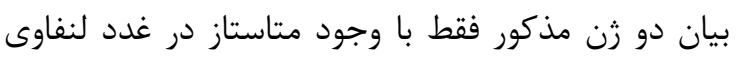

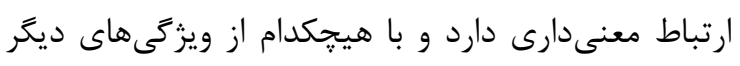

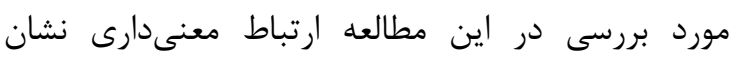

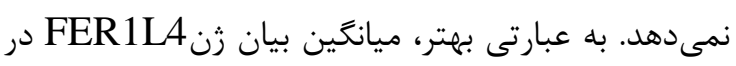

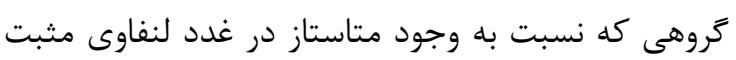

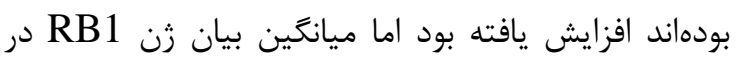

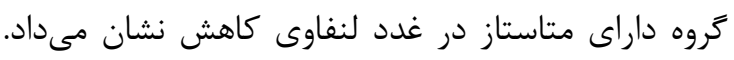

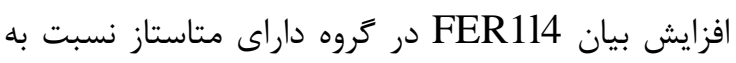
كروه فاقد متاستاز نقش اين مولكول در فرآيند متاستاز

$$
\text { سرطان بستان را كوشزد مى كند. }
$$

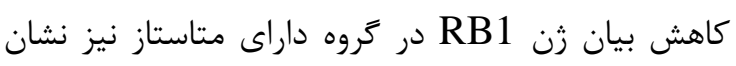

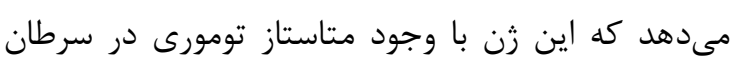

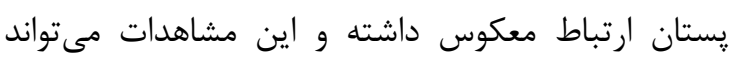

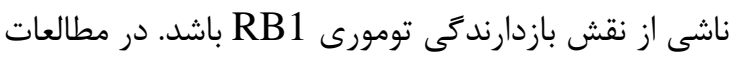

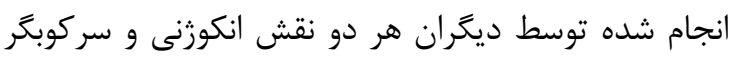

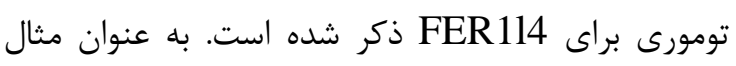

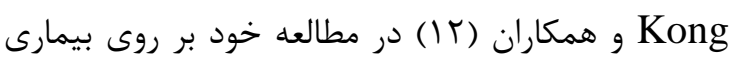

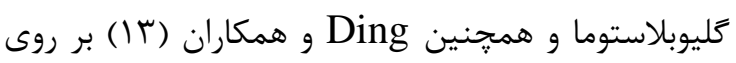

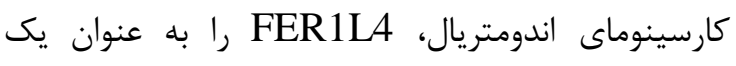
انكوزن در سرطانزايى و ايجاد تومور در بيمارى بانهاى

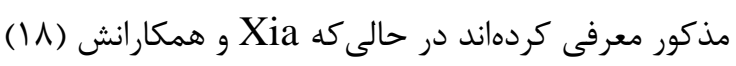

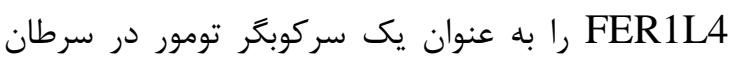

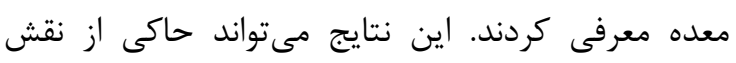

الها كروهى از هاى غير كد كننده مىباشند كه برخى از آنها به عنوان إن مان ماى اندورن

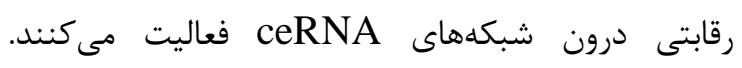
مثال بارزى از اين مولكولهاست كه به صورت

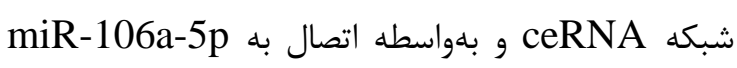

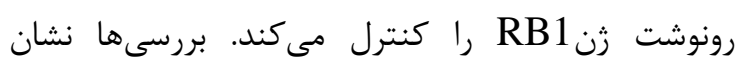

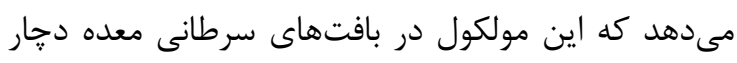

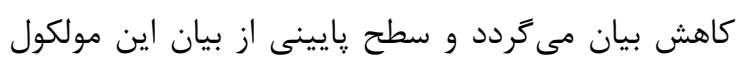

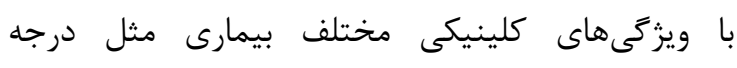

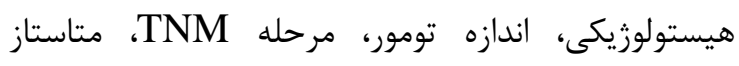

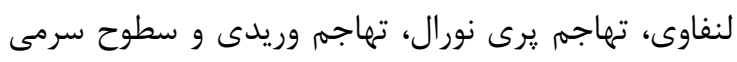

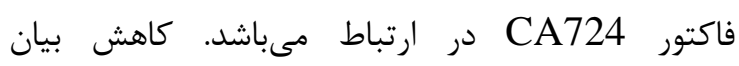
FER1L4 به طور قابل توجهى منجر به سرعت بخشيدن به تكثير سلولى از طريق انتقال سلول از فاز

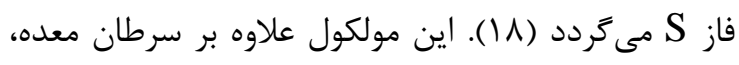

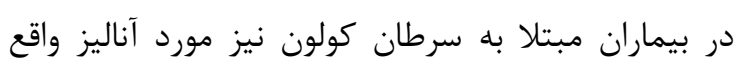

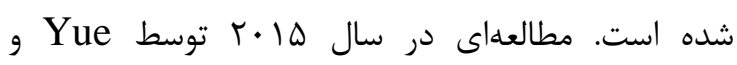

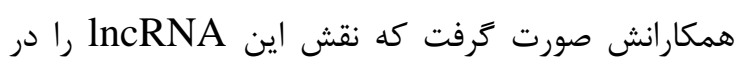

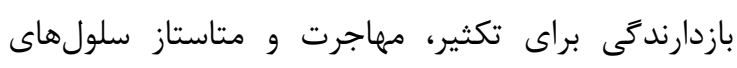

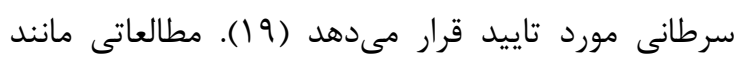

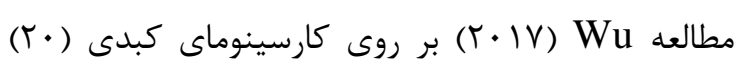

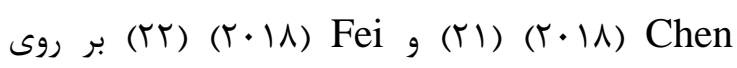

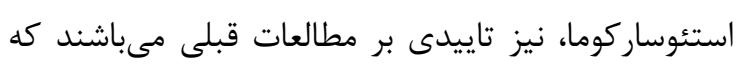

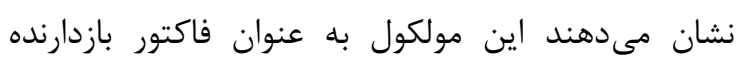

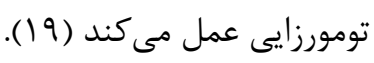
و هing

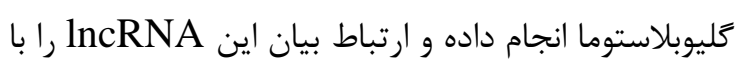

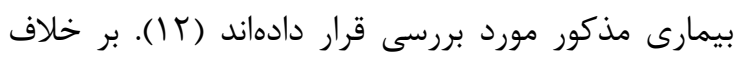

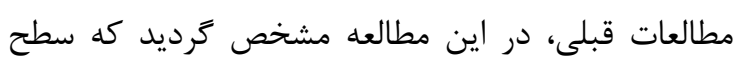
بيان FER1L4 در لاينهاى سلولى كليوما در مقايسه با

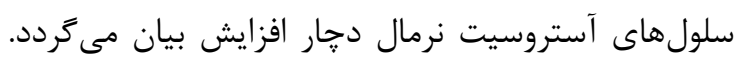

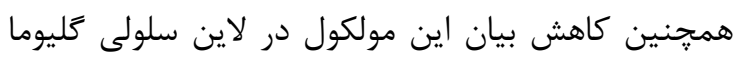

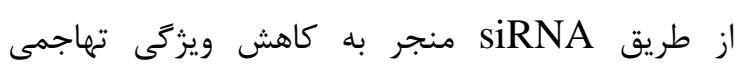

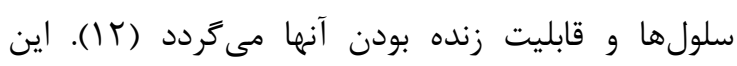

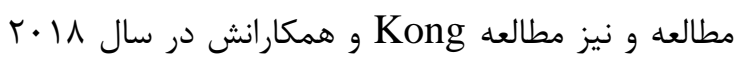

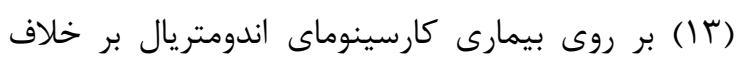

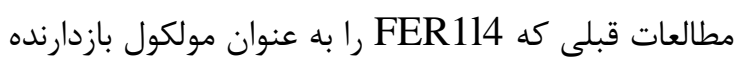

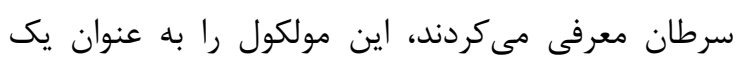


كلينيكى بيمارى در گروه داراى متاستاز نسبت به خروه

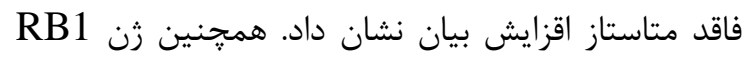

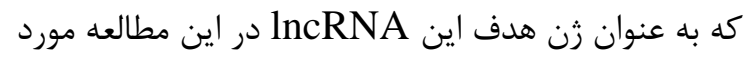
بررسى قرار كرفته است تفاوت معنى دارفى بين بين نمونههاى

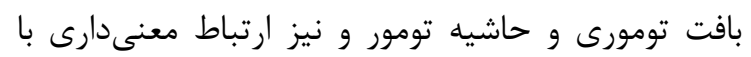

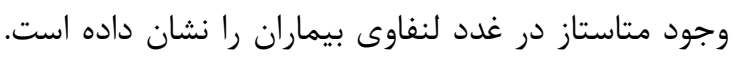

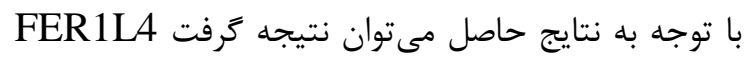
احتمالا بتواند به عنوان يك عامل انكوزن در ايجاد متاستاز

$$
\text { در سرطان يستان عمل نمايد. }
$$

\section{تشكر و قدردانى}

در اين مطالعه از همكاران محترم آزمايشكاه راديوبيولوزى

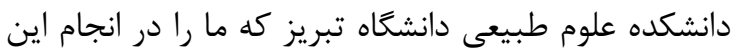

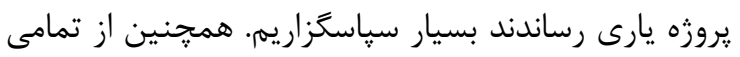

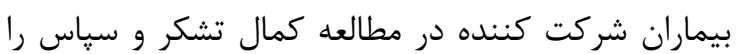

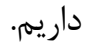

$$
\text { توريسن تعارض منافع اعلام ميى دارند كه هيج تعارض منافعى در }
$$

\section{References}

1. Ma H, Hao Y, Dong X, Gong Q, Chen J, Zhang $\mathrm{J}$, et al. Molecular mechanisms and function prediction of long noncoding RNA. The Scientific World Journal. 2012; 2012: 541786.

2. Abachizadeh K, Moradi-Kouchi A, GhanbariMotlagh A, Kousha A, Shekarriz-Foumani R, Erfani A. Breast Cancer in Iran: levels, Variations and Correlates. Community Health (Salāmat-i ijtimāī). 2018;5(1):11-21.

3. Cao J. The functional role of long non-coding RNAs and epigenetics. Biological procedures online. 2014;16(1):42.

4. Sun M, Kraus WL. From discovery to function: the expanding roles of long noncoding RNAs in physiology and disease. Endocrine reviews. 2015;36(1):25-64.
دو كانه FER114 در سرطانهاى مختلف باشد. در مطالعه

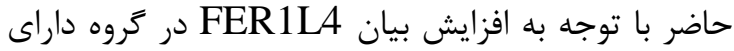

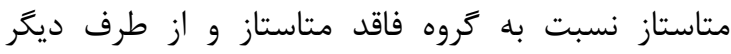

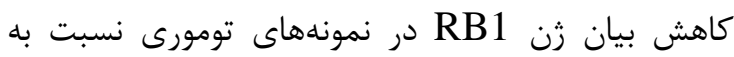

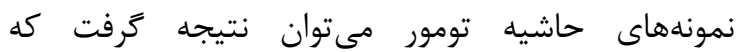

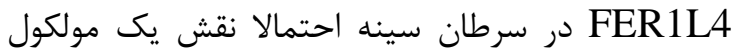
انكوزن را به عهده مى ديرد. كنترل مسيرهاى تنظيمى

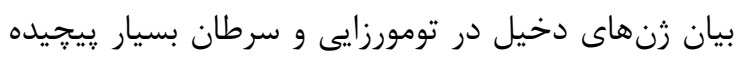

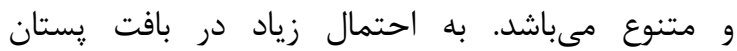

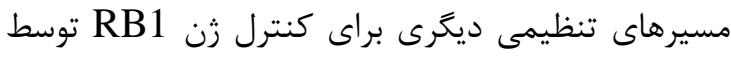
FER1L4 مسيرهاى تنطيمى موجود در معده مى باشد. بنابراين تمامى اين مسيرها به طور كامل شناخته شده

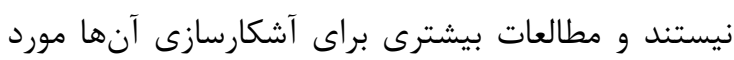

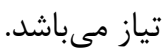

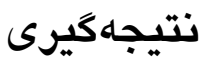

FER1L4 مى گردد در بررسى نمونههاى بافت تومورى سرطان يستان در مقايسه با بافت حاشيه تومور علىرغم افزايش جزئى، تفاوت معنىدارى نشان نداد ولى در بررسى خصوصيات

5. Prensner JR, Chinnaiyan AM. The emergence of IncRNAs in cancer biology. Cancer discovery. 2011;1(5):391-407.

6. Bolha L, Ravnik-Glavač M, Glavač D. Long noncoding RNAs as biomarkers in cancer. Disease markers. 2017; 2017:7243968.

7. Rinn JL, Chang HY. Genome regulation by long noncoding RNAs. Annual review of biochemistry. 2012;81:145-66.

8. Chiu H-S, Somvanshi S, Patel E, Chen T-W, Singh VP, Zorman B, et al. Pan-cancer analysis of $\operatorname{lncRNA}$ regulation supports their targeting of cancer genes in each tumor context. Cell reports. 2018;23(1):297-312. e12.

9. Qi X, Zhang DH, Wu N, Xiao JH, Wang X, $\mathrm{Ma} W$. ceRNA in cancer: possible functions 
and clinical implications. J Med Genet. 2015;52(10):710-8.

10. Song H, Sun W, Ye G, Ding X, Liu Z, Zhang $\mathrm{S}$, et al. Long non-coding RNA expression profile in human gastric cancer and its clinical significances. J Transl Med. 2013;11:225.

11. Liu Z, Shao Y, Tan L, Shi H, Chen S, Guo J. Clinical significance of the low expression of FER1L4 in gastric cancer patients. Tumour Biol. 2014;35(10):9613-7.

12. Ding F, Tang H, Nie D, Xia L. Long noncoding RNA Fer-1-like family member 4 is overexpressed in human glioblastoma and regulates the tumorigenicity of glioma cells. Oncol Lett. 2017;14(2):2379-84.

13. Kong Y, Ren Z. Overexpression of LncRNA FER1L4 in endometrial carcinoma is associated with favorable survival outcome. Eur Rev Med Pharmacol Sci. 2018;22:8113-8.

14. Witkiewicz AK, Chung S, Brough R, Vail P, Franco J, Lord CJ, et al. Targeting the vulnerability of RB tumor suppressor loss in triple-negative breast cancer. Cell reports. 2018;22(5):1185-99.

15. Robinson TJ, Liu JC, Vizeacoumar F, Sun T, Maclean N, Egan SE, et al. RB1 status in triple negative breast cancer cells dictates response to radiation treatment and selective therapeutic drugs. PloS one. 2013;8(11):e78641.

16. Jones RA, Robinson TJ, Liu JC, Shrestha M, Voisin V, Ju Y, et al. RB1 deficiency in triplenegative breast cancer induces mitochondrial protein translation. The Journal of clinical investigation. 2016;126(10):3739-57.

17. Witkiewicz AK, Knudsen ES. Retinoblastoma tumor suppressor pathway in breast cancer: prognosis, precision medicine, and therapeutic interventions. Breast Cancer Research. 2014;16(2):207.

18. Xia T, Chen S, Jiang Z, Shao Y, Jiang X, Li $\mathrm{P}$, et al. Long noncoding RNA FER1L4 suppresses cancer cell growth by acting as a competing endogenous RNA and regulating PTEN expression. Sci Rep. 2015;5:13445.

19. Yue B, Sun B, Liu C, Zhao S, Zhang D, Yu F, et al. Long non-coding RNA Fer-1-like protein 4 suppresses oncogenesis and exhibits prognostic value by associating with miR$106 \mathrm{a}-5 \mathrm{p}$ in colon cancer. Cancer Sci. 2015;106(10):1323-32.

20. Wu J, Huang J, Wang W, Xu J, Yin M, Cheng N, et al. Long non-coding RNA Fer-1like protein 4 acts as a tumor suppressor via miR-106a-5p and predicts good prognosis in hepatocellular carcinoma. Cancer Biomark. 2017;20(1):55-65.

21. Chen ZX, Chen CP, Zhang N, Wang TX. Low-e xpression of 1ncRNA FER1L4 might be a prognostic marker in osteosarcoma. Eur Rev Med Pharmacol Sci. 2018;22(8):2310-4.

23. Fei D, Zhang X, Liu J, Tan L, Xing J, Zhao $\mathrm{D}$, et al. Long Noncoding RNA FER1L4 Suppresses Tumorigenesis by Regulating the Expression of PTEN Targeting miR-18a-5p in Osteosarcoma. Cell Physiol Biochem. 2018;51(3):1364-75. 